\title{
Desain Pengisian Optimal Kendaraan Listrik Berdasarkan Kebutuhan Daya Grid dan Kondisi Grid pada Stasiun Pengisian Kendaraan Listrik Menggunakan Kontroler Logika Fuzzy
}

\author{
Onang Surya Nugroho, Dimas Anton Asfani, dan Daniar Fahmi \\ Jurusan Teknik Elektro, Fakultas Teknologi Industri, Institut Teknologi Sepuluh Nopember (ITS) \\ Jl. Arief Rahman Hakim, Surabaya 60111 \\ E-mail: onang.nugroho@gmail.com, anton@ee.its.ac.id, daniarfahmi@ee.its.ac.id
}

\begin{abstract}
Abstrak - Kendaraan listrik telah menjadi salah satu alternatif dalam menangani isu krisis energi dalam bidang transportasi. Peningkatan jumlah kendaraan listrik yang tidak diiringi oleh sistem manajemen stasiun pengisian yang baik akan memberikan dampak negatif ke sistem distribusi pada jaringan seperti fluktuasi tegangan, drop tegangan, stress tegangan, rendahnya kontinuitas daya sistem, bahkan dapat menyebabkan terjadinya blackout. Diperlukan desain manajemen energi untuk kendaraan listrik pada stasiun pengisian sehingga didapatkan model aliran daya yang optimal antara stasiun pengisian dan grid. Dalam tugas akhir ini akan dirancang desain dan analisis pengisian optimal dengan mempertimbangkan estimasi aliran daya antara stasiun pengisian dengan grid dan kondisi beban pada grid (off-peak / peak) menggunakan kontroler fuzzy logic. Manajemen pengisian ini menggunakan konsep vehicle to vehicle (V2V), vehicle to grid (V2G), maupun grid to vehicle (G2V) yang diatur oleh indek dan rating pengisian hasil skoring rule fuzzy. Dengan dua masukan tersebut di atas, hasil simulasi menunjukkan bahwa sistem berbasis fuzzy dapat meratakan kurva beban puncak kendaraan listrik, mengurangi dampak beban puncak ke grid, dan dapat memberikan keuntungan dari segi biaya berupa saving cost.
\end{abstract}

Kata Kunci-Kendaraan Listrik, Pengisian Optimal, Fuzzy Logic Controller, Vehicle to Vehicle, Vehicle to Grid, Grid yo Vehicle.

\section{PEndahuluan}

$\mathrm{P}$ ENIPISAN cadangan energi fosil telah memberikan dampak serius di berbagai bidang kehidupan, khususnya dalam sektor transportasi. Berdasarkan data dari Energy Information Administration (EIA), bahwa pada tahun 2035 jumlah konsumsi energi fosil meningkat hingga 54\% dan harga energi fosil akan terus naik dalam kurun waktu dua dekade mendatang [1]. Berbagai usaha yang berkaitan dengan pengurangan jumlah konsumsi energi fosil mulai bermunculan. Dalam sektor transportasi, kendaraan listrik telah menjadi solusi yang menjanjikan dalam usaha pengurangan energi fosil dan kendaraan listrik terus berkembang menjadi pasar utama dalam industri otomotif.

Peningkatan jumlah kendaraan listrik yang signifikan dapat memberikan dampak positif maupun negatif ke sistem jaringan distribusi. Kendaraan listrik berpotensi menjadi solusi dalam usaha peak shaving dan valley filling grid dalam kondisi peak load dengan melakukan transfer energi dari baterai kendaraan listrik ke grid di bawah konsep layanan vehicle to grid (V2G) [2]. Di sisi lain, sistem pengisian kendaraan listrik yang acak dan tidak terkontrol dapat menyebabkan dampak yang serius bagi jaringan distribusi seperti fluktuasi tegangan, stres pada sistem distribusi, degradasi kontinuitas daya, masalah teknis, degradasi sistem ekonomi, dan dapat menyebabkan blackout [3].

Untuk menanggulangi masalah tersebut, beberapa studi terkait manajemen aliran daya antara stasiun pengisian dan grid telah dilakukan. Pada referensi [4], dijelaskan studi terkait manajemen aliran daya secara real time pada smart grid dengan mempertimbangkan efisiensi harga dan rugi rugi daya. Namun, studi ini tidak melibatkan sumber energi terbarukan pada sistem, padahal penetrasi sumber energi terbarukan merupakan salah satu usaha dalam pengurangan konsumsi energi fosil. Selain itu, strategi kontrol tidak berdasarkan level prioritas kebutuhan, tetapi berdasarkan seberapa banyak owner kendaraan dapat membayar dan sistem juga tidak membertimbangkan SOC (state of charge), sehingga efisiensi dari layanan sistem vehicle to vehicle (V2V) dan vehicle to grid (V2G) sangat rendah. Pada referensi [5], dijelaskan tentang proses manajemen transfer energi antara stasiun pengisian dan grid dengan memanfaatkan kendaraan listrik sebagai energy storage unit (ESU), di mana baterai kendaraan listrik dapat mentransfer daya ke grid atau sebaliknya. Namun, proses aliran daya dan state of charge (SOC) tidak dipertimbangkan selama proses ini.

Dalam Tugas Akhir ini, didesain sebuah sistem manajemen energi dengan mempertimbangkan estimasi aliran daya antara stasiun pengisian dan grid. Pada grid, diperhatikan kondisi peak atau off peak dari profil beban harian gardu induk. Kontroler logika fuzzy digunakan untuk memutuskan level proritas dan rating pengisian yang diperlukan oleh kendaraan listrik yang terparkir sesuai dengan SOC (state of charge) dan lama parkir (parking duration). Sistem kontroler ini juga dapat memutuskan mode yang paling efisien untuk memaksimalkan penggunaan energi photovoltaic, meminimalisir penggunaan grid, dan pemenuhan SOC kendaraan listrik dengan mengaktifkan mode vehicle to vehicle $(\mathrm{V} 2 \mathrm{~V})$, vehicle to grid (V2G), atau grid to vehicle (G2V). 


\section{DASAR TEORI}

\section{A. Stasiun Pengisian Kendaraan Listrik}

Stasiun pengisian kendaraan listrik merupakan sebuah infrastruktur sumber eksternal untuk pengisian kendaraan listrik [6]. Beberapa klasifikasi stasiun pengisian yang telah banyak digunakan diantaranya residental charging station, charging while parked, fast charging, dan battery swaps.

Sumber energi listrik stasiun pengisian kendaraan listrik ITS berasal dari grid (PLN) dan panel surya (photovoltaic) yang dilengkapi media penyimpanan berupa baterai charging station, sehingga ketiga sumber ini disebut hybrid charging station. Terdapat tiga slot untuk pengisian kendaraan listrik yaitu dua untuk mobil listrik (ezzy 1 dan ezzy 2) dan satu untuk bus listrik. Panel surya (photovoltaic) sebagai energi terbarukan terdiri dari 10 modul dengan kapasitas keluaran 2.000 Watt peak (5 pararel dan 2 seri). Sedangkan baterai charging station sebagai media penyimpanan terdiri dari 12 baterai (VRLA) 2 Volt dengan rating kapasitas total sebesar $1.500 \mathrm{Ah}$

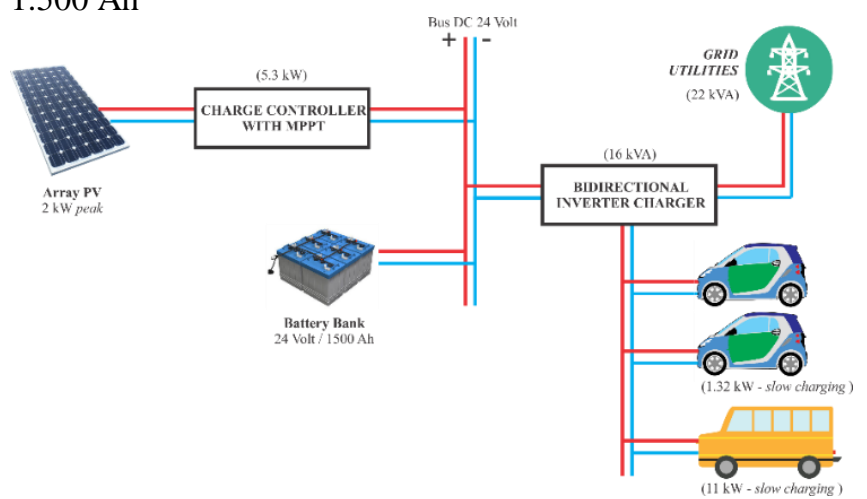

Gambar 1. Skema hybrid stasiun pengisian ITS

\section{B. Manajemen Aliran Daya pada Stasiun Pengisian Kendaraan Listrik}

1. Manajemen Aliran Daya Berdasarkan Mode Operasi

Didasarkan pada sistem hybrid stasiun pengisian, di mana sumber berasal dari panel surya dan grid PLN. Mode operasi ini digunakan untuk menyesuaikan kebutuhan beban dengan ketersediaan sumber pada sistem.

2. Manajemen Aliran Daya Berdasarkan Harga Grid

Manajemen aliran daya ini menggunakan pertimbangan kondisi harga grid, di mana harga grid diasumsikan berbedabeda setiap waktu (harga lebih mahal ketika kondisi grid puncak). Selanjutnya harga grid ini akan menjadi masukan fuzzy logic controller bersama dengan daya pada bus yang juga terdiri dari dua sumber yakni grid dan panel surya.

3. Manajemen Berdasarkan Peak Shaving dan Valley Filling

Merupakan konsep manajemen aliran daya untuk mengurangi kurva beban puncak. Peak shaving merupakan pemotongan kurva beban puncak dengan memberikan daya pada grid, di mana sistem pada stasiun pengisian kendaraan listrik mengalami proses discharging, sehingga daya dialokasikan ke grid untuk mengurangi kurva beban puncak. Sedangkan untuk valley filling merupakan kebalikan dari sistem peak shaving dengan cara sistem pada stasiun pengisian kendaraan listrik mengalami proses charging untuk membuat kurva beban pada kondisi yang diinginkan.

\section{Power Flow Regulation pada Sistem V2G}

1. Agregator dan Stasiun Pengisian

Agregator dibangun untuk memenuhi regulasi aliran daya pada stasiun pengisian skala besar untuk menyediakan layanan charging / discharging [7]. Untuk memenuhi tujuan tersebut, agregator diharuskan memperoleh informasi tentang kapasitas daya dari masing - masing kendaraan listrik yang terparkir dan kemudian menentukan besar daya yang harus disediakan oleh grid untuk ditransfer ke kendaraan listrik.

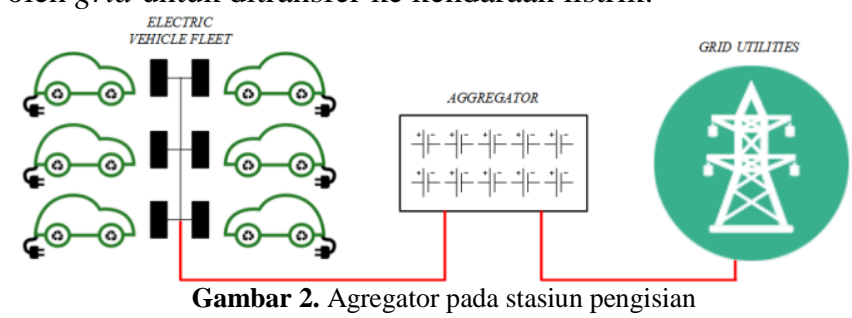

\section{Study of Driving Patterns}

Untuk memprediksi penggunaan energi dari owner kendaraan listrik, pembelajaran tentang driving behaviours sebaiknya dilakukan untuk mendapatkan pemahaman tentang seberapa banyak energi yang dibutuhkan oleh kendaraan listrik dan seberapa banyak energi dapat ditransfer ke grid meliputi jarak tempuh kendaraan listrik per hari, konsumsi energi dari kendaraan listrik, dan SOC (state of charge) baterai ketika mobil tiba di tujuan.

\section{Stasiun Pengisian}

Berfungsi sebagai penghubung antara kendaraan listrik dan grid, stasiun pengisian mempunyai peran yang sangat penting dalam hal komunikasi. Stasiun pengisian juga menjadi pusat kontrol dalam mengatur aliran daya di antara kendaraan listrik dan grid.

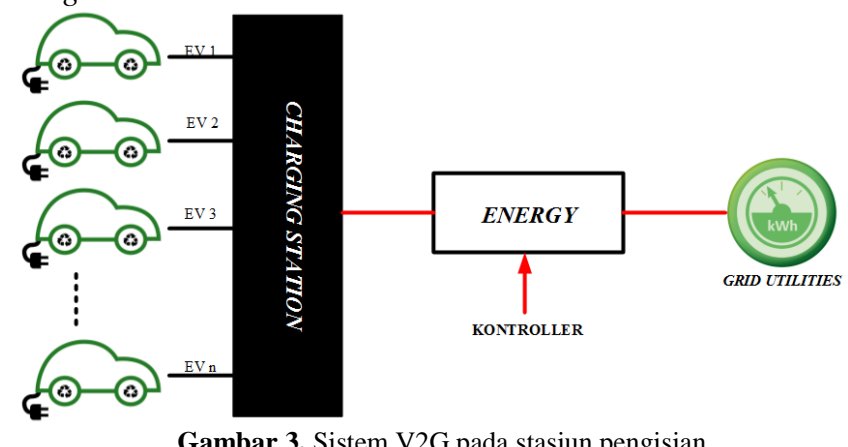

Gambar 3. Sistem V2G pada stasiun pengisian

\section{Fuzzy Logic Controller}

Fuzzy dikenal sebagai kabur / samar-samar. Fuzzy merupakan nilai yang dapat bernilai benar atau salah secara bersamaan [8]. Namun seberapa besar kebenaran dan kesalahannya tergantung pada derajat keanggotaannya (rentang $0-1)$. Logika fuzzy digunakan untuk menterjemahkan suatu besaran yang diekspresikan menggunakan bahasa (linguistik), misalkan besaran kecepatan laju kendaraan yang diekspresikan dengan pelan, agak cepat, cepat, dan sangat cepat. logika fuzzy menunjukkan sejauh mana suatu nilai itu benar dan sejauh mana suatu nilai itu salah. 


\section{PERANCANGAN SIMULASI PENGISIAN OPTIMAL STASIUN PENGISIAN KENDARAAN LISTRIK}

\section{A. Perancangan Sumber}

Perancangan sumber pada penelitian ini menggunakan tiga buah sumber yaitu, panel surya dengan kapasitas total pada kondisi irradiance maksimum adalah 2.000 Watt peak, grid, dan baterai charging sation. Untuk mendapatkan hasil pengisian optimal pada stasiun pengisian kendaraan listrik dibutuhkan penetrasi dari sumber energi terbarukan, sehingga kecenderungan sistem untuk mengambil daya dari grid akan berkurang karena adanya penetrasi sumber energi terbarukan.

\section{B. Perancangan Beban}

Perancangan beban dimodelkan dengan menggunakan referensi spesifikasi dari bus listrik ITS, mobil ezzy 1, dan mobil ezzy 2 sesuai Tabel 1.

Tabel 1.

Beban maksimum kendaraan listrik

\begin{tabular}{llc}
\hline \hline No & \multicolumn{1}{c}{ Beban } & Kebutuhan \\
\hline 1 & Bus Listrik & $36 \mathrm{~kW}$ \\
2 & Mobil Ezzy 1 & $20 \mathrm{~kW}$ \\
3 & Mobil Ezzy 2 & $20 \mathrm{~kW}$ \\
\hline \hline
\end{tabular}

\section{Perancangan Mode Operasi}

Dari Gambar 4, dapat diketahui bahwa proses perancangan aliran daya untuk pengisian optimal kendaraan listrik adalah sebagai berikut:

1. Ketika kendaraan listrik memasuki area parkir, masing masing torch akan menghitung waktu kedatangan (arrival time - At), sensing SOC dari kendaraan, dan owner akan set waktu kepergian (departure time - Dt), sehingga torch akan menghitung lama parkir (parking duration - PD) yang dibutuhkan oleh masing - masing kendaraan listrik.

$$
P D=D_{t}-A_{t}
$$

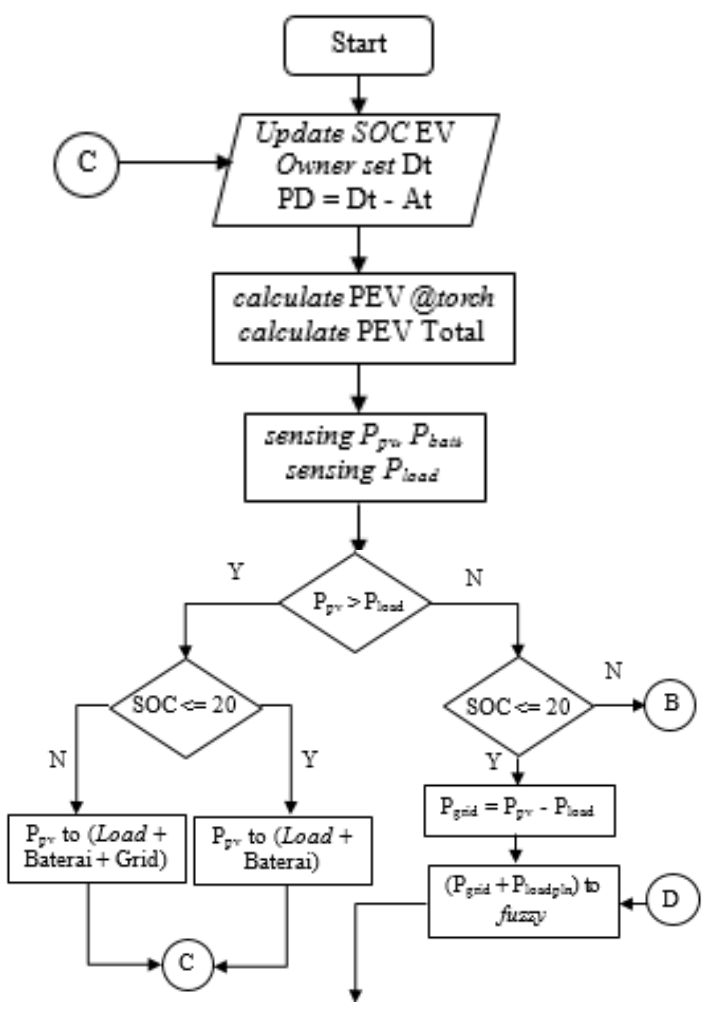

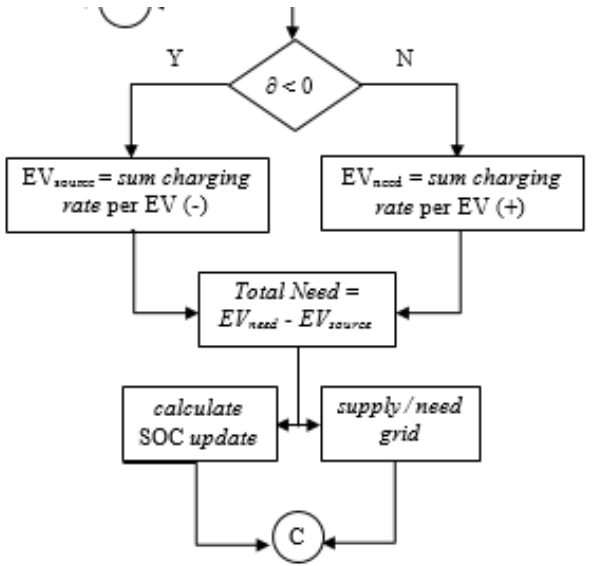

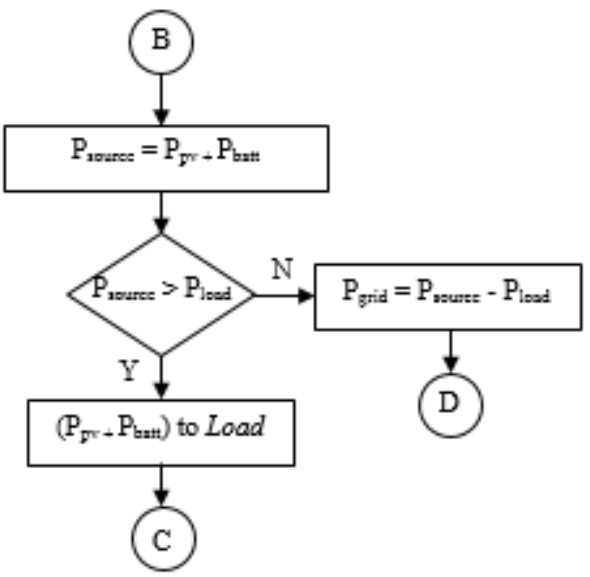

Gambar 4. Flowchart pengisian optimal

2. Perhitungan daya dilakukan pada masing - masing torch sehingga didapatkan kebutuhan dari masing - masing kendaraan listrik (persamaan 10). Setelah itu akan dihitung kebutuhan daya total atau kebutuhan beban.

$$
P E V_{\text {need }}=\frac{100-S O C}{100} \times \frac{B C}{P D}
$$

3. Dengan melakukan sensing $\mathrm{Ppv}, \mathrm{P}_{\text {Batt }}$ (daya baterai charging station), dan PEV_Need_Total (beban keseluruhan mobil), maka akan didapatkan kemungkinan mode operasi aliran daya pada charging station.

Untuk mode operasi dari aliran daya yang mungkin terjadi selama proses pengisian optimal kendaraan listrik dapat dilihat pada Tabel 2.

Tabel 2.

\begin{tabular}{|c|c|c|}
\hline $\begin{array}{c}\text { Mode } \\
\text { Operasi }\end{array}$ & Aliran Daya & Kondisi \\
\hline $\begin{array}{c}\text { Mode } \\
\text { Operasi } 1\end{array}$ & $\mathrm{P}_{\mathrm{pv}}$ to $($ Load + Baterai $)$ & $\begin{array}{l}\mathrm{P}_{\mathrm{pv}}>\text { Pload \&\& SOC } \\
<=20 \%\end{array}$ \\
\hline $\begin{array}{c}\text { Mode } \\
\text { Operasi } 2\end{array}$ & $\begin{array}{l}\mathrm{P}_{\mathrm{pv}} \text { to }(\text { Load }+ \text { Baterai }+ \\
\text { Grid })\end{array}$ & $\begin{array}{l}\mathrm{P}_{\mathrm{pv}}>\text { Pload \&\& SOC }> \\
20 \%\end{array}$ \\
\hline $\begin{array}{c}\text { Mode } \\
\text { Operasi } 3\end{array}$ & $\begin{array}{l}\text { Vehicle to Vehicle } \\
\text { Grid to Vehicle } \\
\text { Vehicle to Grid }\end{array}$ & $\begin{array}{l}\mathrm{P}_{\mathrm{pv}}<\text { Pload \&\& SOC } \\
<=20 \%\end{array}$ \\
\hline Mode & $\begin{array}{l}\left(\mathrm{P}_{\mathrm{pv}}+\mathrm{Baterai}\right) \text { to Load } \\
\text { Vehicle to Vehicle }\end{array}$ & $\begin{array}{l}\mathrm{P}_{\mathrm{pv}}<\text { Pload \&\& SOC }> \\
20 \%\end{array}$ \\
\hline Operasi 4 & $\begin{array}{l}\text { Grid to Vehicle } \\
\text { Vehicle to Grid }\end{array}$ & \\
\hline
\end{tabular}

Mode operasi pengisian kendaraan listrik

Mode operasi 3 dan 4 memungkinkan terjadinya layanan $\mathrm{V} 2 \mathrm{~V}, \mathrm{~V} 2 \mathrm{G}$, dan $\mathrm{G} 2 \mathrm{~V}$ dengan menggunakan rating pengisian pada Tabel 3. 
Tabel 3.

Rating pengisian

\begin{tabular}{cll}
\hline \hline Level & \multicolumn{3}{c}{ Power Requirement } & Charging / Discharging Rate \\
\hline $\mathrm{A}$ & $10 \mathrm{~kW} \leq P E V_{-}$Need $<15$ & $11 \mathrm{~kW}$ \\
& $\mathrm{~kW}$ & \\
$\mathrm{~B}$ & $5 \mathrm{~kW} \leq P E V_{-}$Need $<10$ & $4.75 \mathrm{~kW}+4 \mathrm{~kW} *$ index \\
& $\mathrm{kW}$ & \\
$\mathrm{C}$ & $2 \mathrm{~kW} \leq P E V_{-}$Need $<5$ & $5 \mathrm{~kW} *$ index \\
& $\mathrm{kW}$ & \\
$\mathrm{D}$ & $P E V \_$Need $<2 \mathrm{~kW}$ & $-3 \mathrm{~kW}+5 \mathrm{~kW} *$ index \\
\hline \hline
\end{tabular}

\section{Perancangan Fuzzy Logic Controller}

Kontroler logika fuzzy digunakan untuk mengatur transfer daya yang terjadi antara stasiun pengisian dan grid baik berupa vehicle to vehicle, vehicle to grid, maupun grid to vehicle untuk mendapatkan nilai optimal dengan tujuan mengurangi beban grid ketika terjadi penetrasi kendaraan listrik dalam jumlah banyak. Kontroler logika fuzzy yang digunakan adalah tipe fuzzy-mamdani.

Gambar 5 menunjukkan membership function dari $P_{\text {gridtotal }}$ dengan range [9198 1.55e+04]. Gambar 6 menunjukkan membership function $P_{\text {grid }}$ dengan range $[-3.3 \mathrm{e}+040]$, dan membership function index charging ditunjukkan pada Gambar 7. Sedangkan tampilan untuk surface fuzzy dapat dilihat pada Gambar 8. Penentuan rule fuzzy menggunakan 25 rule yang terbagi menjadi tabel 5 x 5 seperti yang ditunjukkan pada Tabel 4.

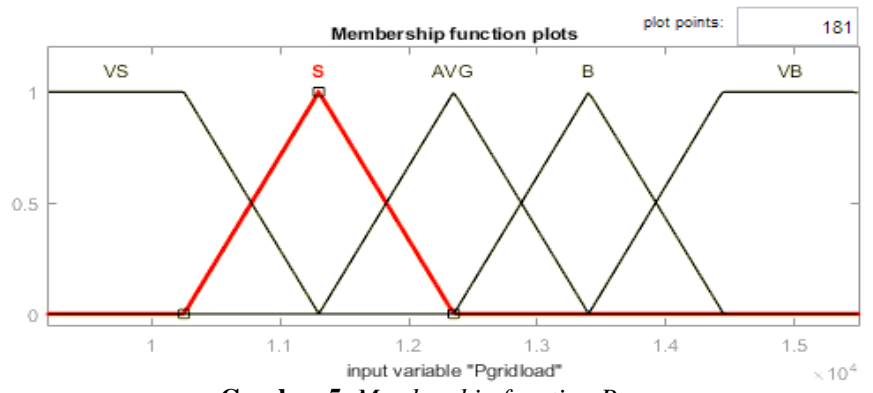

Gambar 5. Membership function $P_{\text {gridload }}$

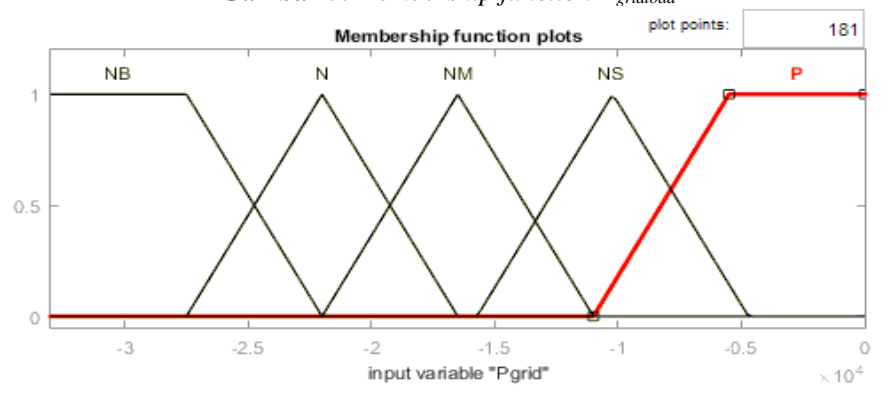

Gambar 6. Membership function $P_{\text {grid }}$

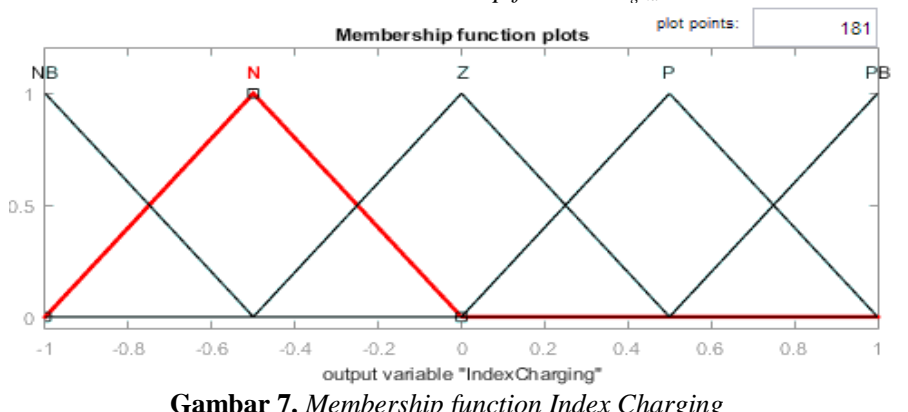

Gambar 7. Membership function Index Charging

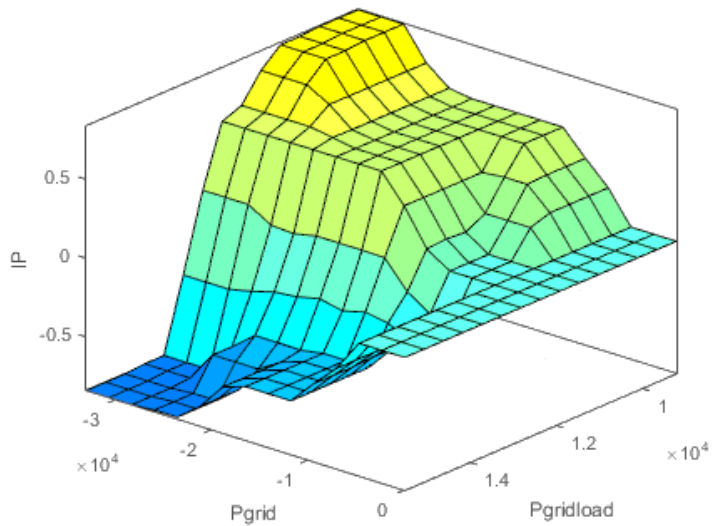

Gambar 8. Surface fuzzy

Tabel 4.

Rule pada fuzzy

\begin{tabular}{cccccc}
\hline \hline Pgrid & $\begin{array}{c}\text { Negative } \\
\text { Big }\end{array}$ & Negative & $\begin{array}{c}\text { Negative } \\
\text { Medium }\end{array}$ & $\begin{array}{c}\text { Negative } \\
\text { Small }\end{array}$ & Positive \\
Pgridload & $\mathrm{P}$ & $\mathrm{P}$ & $\mathrm{P}$ & $\mathrm{P}$ & $\mathrm{Z}$ \\
\hline Very Small & $\mathrm{PB}$ & $\mathrm{P}$ & $\mathrm{P}$ & $\mathrm{Z}$ & $\mathrm{Z}$ \\
Small & $\mathrm{PB}$ & $\mathrm{P}$ & $\mathrm{P}$ & $\mathrm{Z}$ & $\mathrm{Z}$ \\
Average & $\mathrm{P}$ & $\mathrm{N}$ & $\mathrm{N}$ & $\mathrm{N}$ & $\mathrm{Z}$ \\
Big & $\mathrm{NB}$ & $\mathrm{NB}$ & $\mathrm{N}$ & $\mathrm{N}$ & $\mathrm{Z}$ \\
VeryBig & $\mathrm{NB}$ & $\mathrm{N}$ & & & \\
\hline \hline
\end{tabular}

\section{ANALISIS DAN PEMBAHASAN}

\section{A. Penentuan Kondisi}

Simulasi dilakukan pada dua jenis kondisi yakni kondisi 1 sistem dibebani dengan 3 buah mobil dengan kapasitas baterai sesuai dengan mobil ezzy ITS $20 \mathrm{kWh}$. Mobil A dengan SOC $0 \%$ dengan parking duration 1 jam, mobil B dengan SOC 20 $\%$ dengan parking duration 3 jam, mobil C dengan SOC $80 \%$ dengan parking duration 5 jam. Sedangkan kondisi 2 sistem dibebani dengan 3 buah kendaraan listrik yang terdiri dari sebuah bus dan dua buah mobil. Bus memiliki SOC $90 \%$ dengan parking duration 6 jam, mobil A memiliki SOC $0 \%$ dengan parking duration 1 jam, dan mobil B memiliki SOC 0 $\%$ dengan parking duration 1.5 jam. Simulasi dilakukan pada sistem menggunakan fuzzy dan tanpa menggunakan fuzzy. Grafik perbandingan total kebutuhan beban pada Gambar 9 menunjukkan perbandingan kebutuhan baik ketika sistem tidak menggunakan fuzzy maupun ketika sistem menggunakan fuzzy.

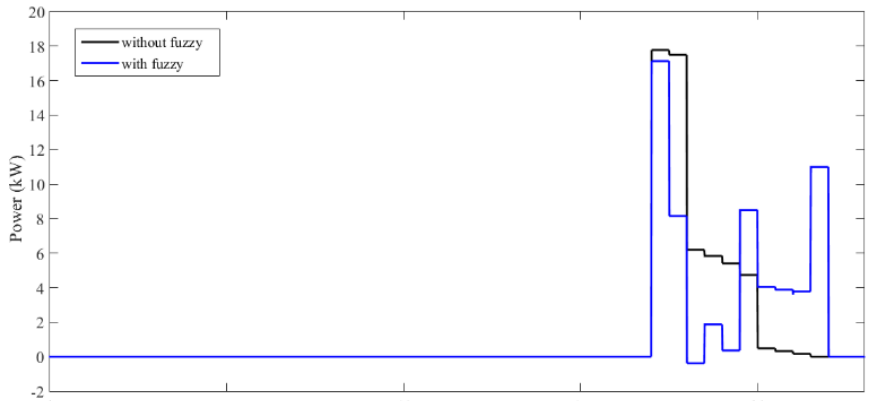

Time (hour)

Gambar 9. Perbandingan total kebutuhan beban kondisi 1 


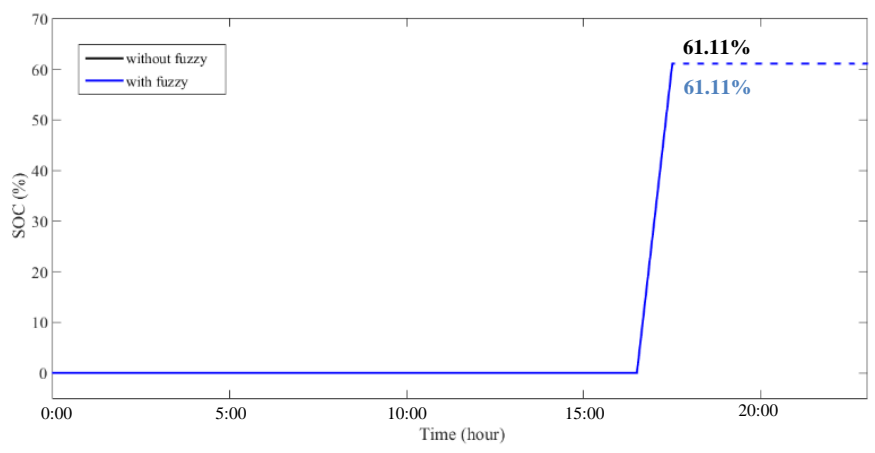

Gambar 10. Perbandingan SOC mobil A kondisi 1

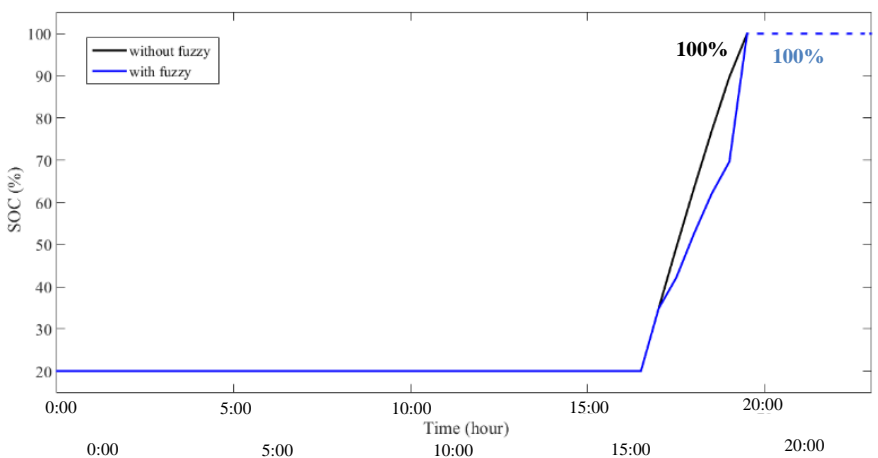

Gambar 11. Perbandingan SOC mobil B kondisi 1

Pada setengah jam pertama (17:00 - 17:30) dapat diketahui bahwa sistem berbasis fuzzy dapat menurunkan daya sebesar $0,64 \mathrm{~kW}$ dari $17,77 \mathrm{~kW}$ ke 17,13 kW. Sedangkan pada setengah jam berikutnya (17:30 - 18:00), sistem berbasis fuzzy dapat menurunkan daya sebesar $9,34 \mathrm{~kW}$ dari $17,49 \mathrm{~kW}$ ke $8,15 \mathrm{~kW}$.

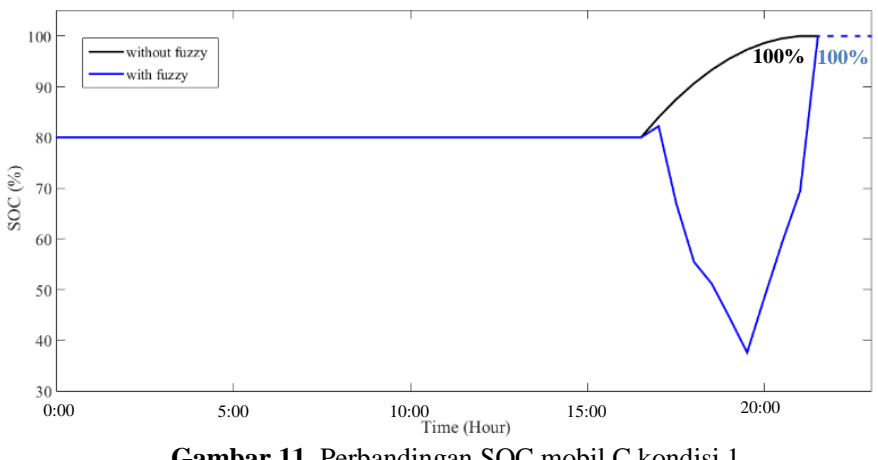

Gambar 11. Perbandingan SOC mobil C kondisi 1

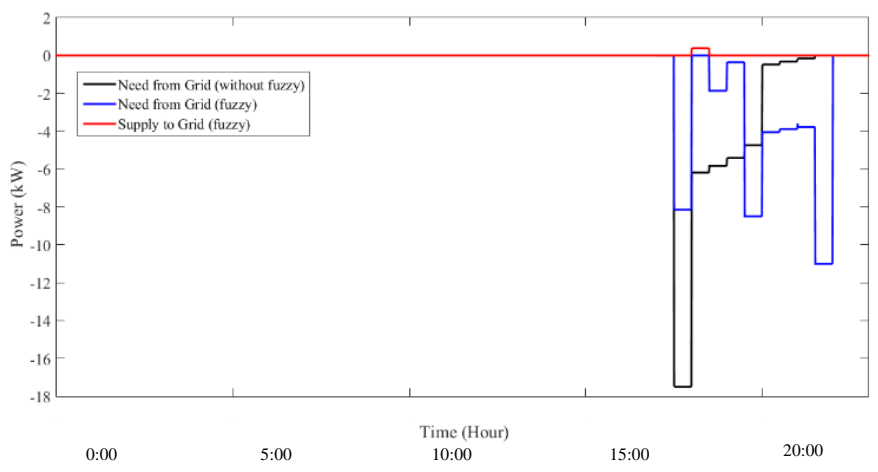

Gambar 12. Perbandingan kebutuhan daya grid kondisi 1
Hal ini terjadi karena ada kontribusi transfer daya (vehicle-tovehicle) dari mobil $\mathrm{C}$ ke mobil lainnya, sehingga kebutuhan daya dari grid dapat ditekan seminimal mungkin. Pemotongan permintaan beban juga terus terjadi pada jam 18:00 - 20:00 karena kontribusi transfer daya dari mobil C. Beban puncak pada sistem menggunakan fuzzy terjadi pada setengah jam terakhir ketika mobil $\mathrm{C}$ akan mencapai departure time. Meskipun permintaan beban dari mobil $\mathrm{C}$ tergolong besar namun beban puncak tersebut tidak berdampak pada grid dikarenakan grid pada kondisi normal. Gambar 10 menunjukkan perbandingan SOC dari mobil A. Dari grafik tersebut dapat diketahui bahwa baik sistem menggunakan fuzzy maupun tidak menggunakan fuzzy sama-sama menghasilkan SOC akhir sebesar $61,11 \%$ dan kedua grafik identik sama. Sedangkan perbandingan SOC dari mobil B dapat dilihat pada Gambar 11. Sistem menggunakan fuzzy maupun tidak, menghasilkan SOC akhir yang sama sebesar $100 \%$. Perbedaannya bahwa ketika sistem menggunakan fuzzy, grafik terlihat lebih landai. Hal tersebut terjadi karena kontroler FLC mengatur permintaan beban sesuai dengan kondisi grid sehingga dapat mengurangi dampak berlebihan ke grid. Gambar 11 menunjukkan perbandingan SOC dari mobil C. Sistem baik menggunakan fuzzy maupun tidak, menghasilkan SOC akhir sebesar $100 \%$. Perbedaan terletak pada karateristik sistem menggunakan fuzzy, di mana pada jam 17:30 sistem berbasis fuzzy mengontrol mobil C untuk melakukan discharge dan transfer daya ke mobil lain (vehicleto-vehicle), sedangkan sistem tidak menggunakan fuzzy tidak mempunyai kemampuan untuk vehicle-to-vehicle. Gambar 12 menunjukkan perbandingan kebutuhan daya grid dari keseluruhan beban mobil. Dari grafik dapat terlihat bahwa sistem menggunakan fuzzy dapat mengurangi permintaan daya dari grid sebesar $9.34 \mathrm{~kW}$ pada setengah jam ke dua (17:30 18:00) dan terus berlanjut sampai 19:30. Selain itu, sistem menggunakan fuzzy mempunyai kemampuan untuk melakukan layanan vehicle-to-grid (V2G) dan dari grafik telihat bahwa V2G terjadi pada jam 18:00 - 18:30. Sistem berbasis fuzzy akan meratakan permintaan beban puncak sesuai dengan kondisi grid.

Grafik perbandingan total kebutuhan beban pada Gambar 13 menunjukkan perbandingan kebutuhan baik ketika sistem tidak menggunakan fuzzy maupun ketika sistem menggunakan fuzzy kondisi 2. Pada jam 17:30 - 18:00 dapat diketahui bahwa sistem berbasis fuzzy dapat menurunkan daya sebesar $6,98 \mathrm{~kW}$ dari $22,44 \mathrm{~kW}$ ke $15,51 \mathrm{~kW}$.

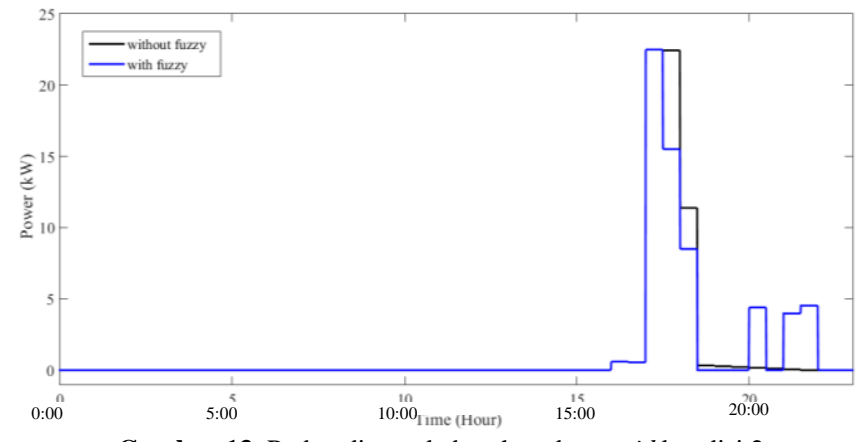

Gambar 13. Perbandingan kebutuhan daya grid kondisi 2 

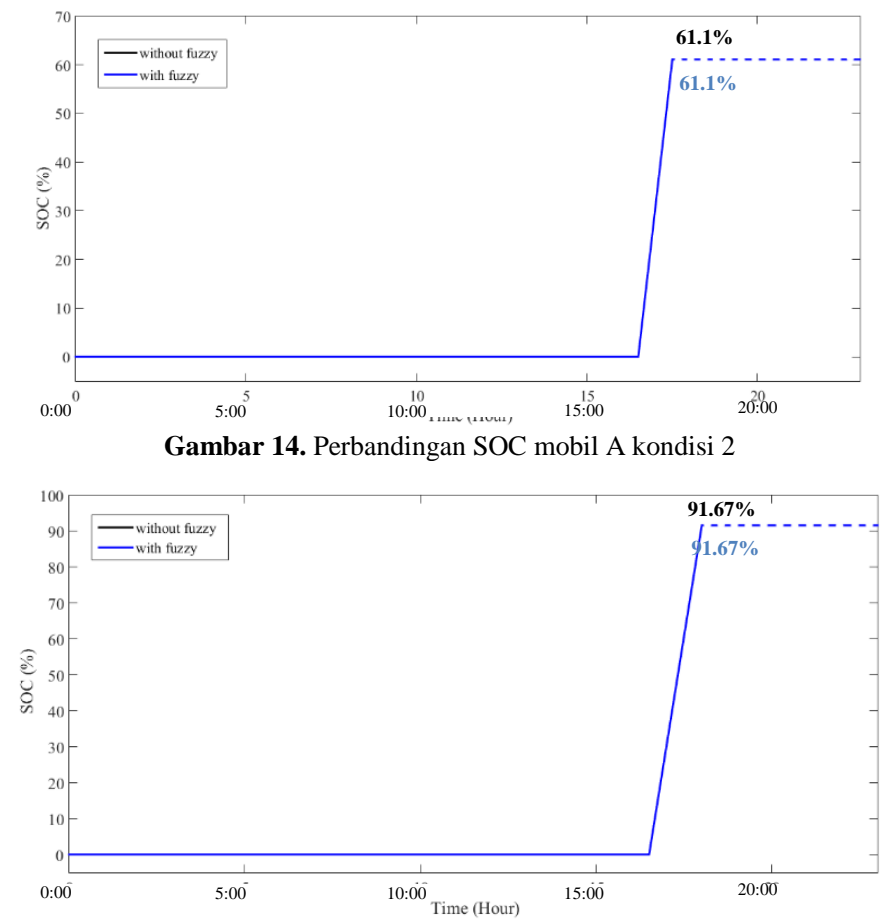

Gambar 15. Perbandingan SOC mobil B kondisi 2
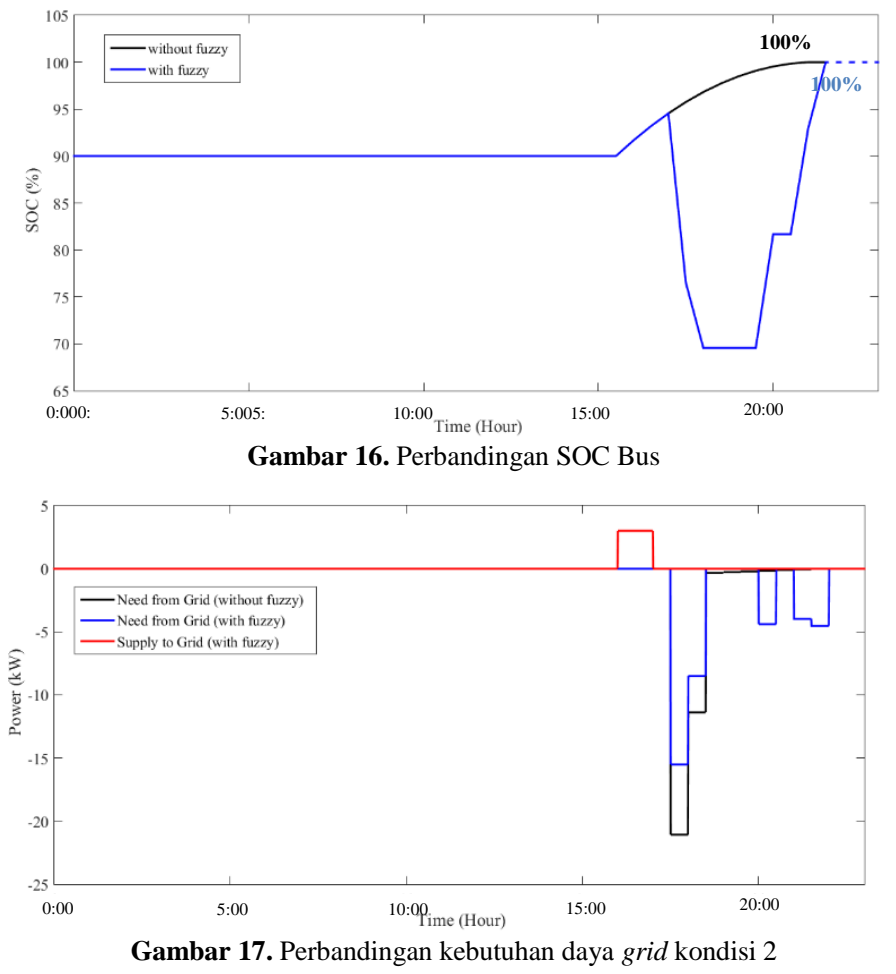

Sedangkan pada setengah jam berikutnya (18:00 - 18:30), sistem berbasis fuzzy dapat menurunkan daya sebesar $2,88 \mathrm{~kW}$ dari 11,38 kW ke 8,5 kW. Hal ini terjadi karena ada kontribusi transfer daya (vehicle-to-vehicle) dari bus ke mobil lainnya, sehingga kebutuhan daya dari grid dapat ditekan seminimal mungkin. Beban puncak pada sistem menggunakan fuzzy terjadi pada sekitar dua jam terakhir ketika bus akan mencapai departure time. Meskipun permintaan beban dari bus tergolong besar namun beban puncak tersebut tidak berdampak pada grid dikarenakan grid pada kondisi normal.
Gambar 14 menunjukkan perbandingan SOC dari mobil A. Dari grafik tersebut dapat diketahui bahwa baik sistem menggunakan fuzzy maupun tidak menggunakan fuzzy samasama menghasilkan SOC akhir sebesar 61,11\% dan kedua grafik identik sama. Perbandingan SOC dari mobil B dapat dilihat pada Gambar 15. Sistem menggunakan fuzzy maupun tidak, menghasilkan SOC akhir yang sama sebesar 91,67\% dan grafik keduanya identik sama. Gambar 16 menunjukkan perbandingan SOC dari bus. Sistem baik menggunakan fuzzy maupun tidak, menghasilkan SOC akhir sebesar $100 \%$. Perbedaan terletak pada karateristik sistem menggunakan fuzzy, di mana pada jam 16:00 sistem berbasis fuzzy mengontrol bus untuk melakukan discharge dan transfer daya ke grid (vehicle-to-grid) dan pada jam 17:30 - 18.30 transfer daya mobil lain (vehicle-to-vehicle), sedangkan sistem tidak menggunakan fuzzy tidak mempunyai kemampuan untuk melakukan layanan vehicle-to-vehicle. Gambar 17 menunjukkan perbandingan kebutuhan daya grid dari keseluruhan beban kendaraan listrik. Dari grafik dapat terlihat bahwa sistem menggunakan fuzzy dapat mengurangi permintaan daya dari grid sebesar 5,56 kW pada jam 17:30 18:00 dan terus berlanjut sampai 18:30 dengan besar daya $2,88 \mathrm{~kW}$. Selain itu, sistem menggunakan fuzzy mempunyai kemampuan untuk melakukan layanan vehicle-to-grid (V2G) dan dari grafik telihat bahwa V2G terjadi pada jam 16:00 17:00 sebesar $3 \mathrm{~kW}$. Sistem berbasis fuzzy akan meratakan permintaan beban puncak sesuai dengan kondisi grid.

\section{B. Analisis Performansi Biaya}

Dalam menganalisis performansi biaya diperlukan grafik perbandingan kebutuhan daya grid dari kondisi 1 dan kondisi 2, harga jual per kWh dari PLN, harga beli per kWh dari PLN, dan karateristik kondisi grid. Untuk kondisi grid digunakan data dari gardu Sukolilo I pada yang dibagi menjadi 5 klasifikasi beban (very small, small, average, big, dan very big) seperti pada Tabel 5.

Tabel 5.

Klasifikasi beban dan Faktor K

\begin{tabular}{clc}
\multicolumn{3}{c}{ Klasifikasi beban dan Faktor K } \\
\hline \hline Klasifikasi & \multicolumn{1}{c}{ Beban $(\mathbf{k W})$} & Faktor K \\
\hline VS & $9198-10457.4$ & 1 \\
S & $10457.4-11716.8$ & 1 \\
AVG & $11716.8-12976.2$ & 1 \\
B & $12976.2-14235.6$ & 1.4 \\
VB & $14235.6-15495$ & 2 \\
\hline \hline
\end{tabular}

Sedangkan untuk harga jual per kWh dari PLN digunakan data tariff adjusment dari PT PLN Persero untuk kelas tegangan menengah dengan harga ( $\mathrm{K}$ x Rp. 959.84,-- per kWh) ketika kondisi waktu beban puncak dan Rp. 959.84 ketika kondisi luar waktu beban puncak. Untuk harga beli per kWh dari PLN diasumsikan sama dengan harga beli dari PLN (K x Rp. 959.84,- per kWh) ketika kondisi waktu beban puncak dan Rp. 959.84,- ketika waktu di luar beban puncak. Analisis performansi biaya menunjukkan untuk kondisi 1 sistem sebelum menggunakan fuzzy menghabiskan biaya sejumlah $\mathrm{Rp}$ 32.313,509,- dan setelah menggunakan sejumlah $\mathrm{Rp}$. 27.199,11 sehingga sistem berbasis fuzzy dapat saving sebesar Rp. 5.114,399,-. Untuk biaya kondisi 2 sebelum menggunakan fuzzy sejumlah Rp. 28.631,36,- dan setelah menggunakan fuzzy sejumlah Rp. 21.868,5 sehingga dapat saving Rp. 6.752,86,-. 


\section{KESIMPULAN}

Berdasarkan hasil simulasi dari pengisian optimal kendaraan listrik berdasarkan estimasi aliran daya dan kondisi beban grid menggunakan kontroler logika fuzzy, dapat disimpulkan beberapa hal sebagai berikut sesuai hasil analisis kondisi 1 dan kondisi 2. Sistem berbasis fuzzy dapat memenuhi kebutuhan SOC dari kendaraan listrik saat departure time hingga mencapai maksimal $100 \%$ tergantung dari berapa lama waktu pengisian, sistem berbasis fuzzy dapat menurunkan beban puncak kendaraan listrik, sistem berbasis fuzzy dapat mengurangi dampak ke grid dengan adanya peak shaving dan valley filling berdasarkan kondisi grid, dan sistem berbasis fuzzy dapat menghemat pengeluaran biaya jika dibandingkan dengan sistem tidak menggunakan fuzzy seperti pada kondisi 1 dapat saving 15,8\% dan kondisi 2 dapat saving $23,6 \%$.

\section{DAFTAR PUSTAKA}

[1] www.eia.gov diakses pada Maret 2016

[2] Mukesh Singh, Student Member, IEEE, Praveen Kumar, Member, IEEE, and Indriani Kar, Member IEEE, "A Multi Charging Station for Electric Vehicles and Its Utilization for Load Management and the Grid Support", IEEE Transaction on Smart Grid., Vol. 4, no. 2, June 2013

[3] Tan Ma, Osama A . Mohammed, Fellow, IEEE, "Optimal Charging of Plug-in Electric Vehicles for a Car-Park Infrastructure", IEEE Transactions On Industry Applications, Vol. 50, No. 4, July/August 2014.

[4] S. Deilami, A. S. Masoum, P. S. Moses, and M. A. S. Masoum, "Realtime Coordination of Plug-In Electric Vehicle Charging in Smart Grids to Minimize Power Losses and Improve Voltage Profile", IEEE Trans. Smart Grid, vol. 2, no. 3, pp. 456-467, Sep. 2011.

[5] Preetham Goli, Student member, IEEE, and Wajiha Shireen, Senior member, IEEE, "Photovoltaic Charging Station for Plug-In Hybrid Electrical Vehiclees in a Smart Grid Environment". IEEE Transaction on Smart Grid., 978-1-4577-2159-5.

[6] www.wikipedia.org/Charging_Station diakses pada Maret 2016

[7] Juan Jesús Alonso Ayuso, "Real-Time Modeling of Vehicle to Grid System”. Student Report. Ingenieria Industrial (ICAI). Aalborg University. Pontoppidanstræde. 2012-2013

[8] Martin Hellmann, “Fuzzy Logic Introduction”, March, 2001 